\title{
Marshall Islands
}

National Cancer Institute

\section{Source}

National Cancer Institute. Marshall Islands. NCI Thesaurus. Code C16822.

A group of atolls and reefs in the North Pacific Ocean, about one-half of the way from Hawaii to Australia, south of Wake Island and north of Nauru. 